\title{
A unique rearrangement of PDGFRa and ETV6 in a patient with acute myeloid leukemia with myelodysplasia-related changes progressed from chronic myelomonocytic leukemia
}

\author{
Prasad Koduru ${ }^{*}$, Naga Guruju ${ }^{1,2}$, Prapti Patel ${ }^{3}$, Jiadi Wen', Kathleen Wilson ${ }^{1}$ and Sara Monaghan ${ }^{1}$
}

*Correspondence: Prasad.Koduru@UTsouthwestern.edu

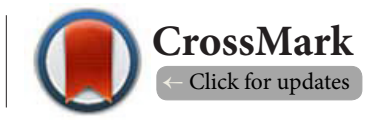

'Department of Pathology, UT Southwestern Medical Center, Dallas, TX 75390, USA.

IIntegrated Genetics (Labcorp), 2000 Vivigen Way, Santa Fe, NM. 87505, USA.

${ }^{3}$ Department of Medicine, Division of Hematology and Oncology, UT Southwestern Medical Center, Dallas, TX 75390, USA.

\begin{abstract}
Platelet derived growth factor receptor alpha (PDGFRa) undergoes different types of rearrangements creating fusion genes in myeloid neoplasms. Cryptic deletion at $4 \mathrm{q} 12$ creating FIP1L1/PDGFR $\alpha$ fusion is the most frequent and is associated with hypereosinophilia. The other infrequent but recurrent abnormality involving PDGFRa seen in myeloid neoplasms is a $t(4 ; 12)(q 12 ; \mathrm{p} 13)$, which creates a fusion gene with $E T V 6$ and activates ETV6 via the tyrosine kinase domain of the PDGFRa. We characterized a new $\mathrm{t}(4 ; 12 ; 6)$ translocation which developed during transformation to acute myeloid leukemia (AML) in a patient with chronic myelomonocytic leukemia (CMML). Standard G-band karyotype analysis and fluorescence in-situ hybridization study (FISH) analysis with a tricolor 4q12 probe and ETV6 was performed on the bone marrow (BM) involved by AML. The karyotype showed a $\mathrm{t}(4 ; 12 ; 6)(\mathrm{q} 12 ; \mathrm{p} 13 ; \mathrm{p} 21.3)$. FISH showed fusion between PDGFRa and ETV6. Patient did not respond to treatment with imatinib or to standard induction chemotherapy for AML, and expired 11 months from diagnosis. This is the first report of a variant $\mathrm{t}(4 ; 12 ; 6)$ and ETV6/PDGFRa fusion that developed during transition from CMML to AML and did not respond to imatinib.
\end{abstract}

Keywords: CMML, transformed AML, ETV6/PDGFRa fusion

\section{Introduction}

Morphological and cytogenetic features categorize myeloid neoplasms into myelodysplastic syndromes (MDS), myelodysplastic/ myeloproliferative neoplasms (MDS/MPN), myeloproliferative neoplasms (MPN) and AML [1]. Specific genetic abnormalities are identified in some subtypes of these diseases. These abnormalities frequently target transcriptional factors involved in controlling cell proliferation and differentiation and are associated with different clinical outcomes. Balanced chromosome rearrangements that lead to gene fusions are frequent in AML. In contrast, gain and/or loss of chromosomes or chromosome segments are frequent in MDS, and in MDS/MPN. CMML is a myeloid neoplasm with features characteristic of both a MDS and MPN [2]. Persistent peripheral blood (PB) monocytosis and less than $20 \%$ blasts are major features of CMML. Clonal cytogenetic abnormalities have been reported in about 30\% of these patients; these include trisomy 8 , and monosomy 7 or del(7q), but none are specific to CMML [3-6]. About $15-20 \%$ of these patients progress to $A M L$, and the transformation is ac- companied by increasing complexity of genetic abnormalities.

An interstitial cryptic deletion within chromosome band $4 q 12$ is a recurrent abnormality in chronic myeloid neoplasms with hypereosionophilia. This deletion fuses $5^{\prime}$-FIP1L1 with the $3^{\prime}-P D G F R a$ and leads to constitutive activation of PDGFRa. This abnormality is also rarely seen in AML or precursor Tlymphoblastic lymphoma [7]. Patients with FIP1L1/PDGFRa fusion respond well to treatment with imatinib [8-11]. Other infrequent rearrangements of $4 q 12$ are translocations with several other regions in the genome, and each of these affect the negative regulatory domain of PDGFRa. These patients usually respond to treatment with imatinib.

ETV6, located at $12 \mathrm{p} 13$ belongs to ets family of transcription factors [12], and codes for ubiquitously expressed nuclear protein that plays an important role in hematopoiesis in BM [13]. Rearrangement of ETV6 with PDGFRa (at $4 \mathrm{q} 12$ ) has been reported in AML, but more frequently involves other translocation partners that leads to fusion genes with tyrosine kinases or transcription factors [14-16]. Other molecular alterations 
Koduru et al. Hematology and Leukemia 2016,

http://www.hoajonline.com/journals/pdf/2052-434X-4-1.pdf

doi: 10.7243/2052-434X-4-1

of leukemogenic nature in ETV6 include deletion leading to haploinsufficiency and heterozygous mutations that result in loss of tumor suppressor activity [17-19]. Here we report the clinical, pathologic, and cytogenetic features of a patient with AML with myelodysplasia-related changes that had a $\mathrm{t}(4 ; 12 ; 6)(\mathrm{q} 12 ; \mathrm{p} 13 ; \mathrm{p} 21)$ and had developed as a transformation from CMML.

\section{Clinical history}

The patient, a 70 year old male, initially presented with progressive weakness and chest pain. The complete blood count (CBC) revealed a white blood cell count (WBC) of $100.0 \times 10^{9} / \mathrm{L}$. The BM was hypercellular with a granulocytic predominance, 5-10\% blasts and a normal karyotype. Tests for JAK2 V617F and $B C R / A B L 1$ were negative and a diagnosis of CMML was rendered. Treatment included high dose hydroxyurea and allopurinol, which resulted in an adequate reduction of the WBC. Treatment was changed to azacytidine, but the patient was admitted with chest pain after six cycles of therapy (i.e., 8 months after initial diagnosis).

Upon readmission the $\mathrm{CBC}$ revealed WBC of $223.9 \times 10^{\circ} / \mathrm{L}$, hemoglobin $7.7 \mathrm{~g} / \mathrm{dL}$, and platelets $27 \times 10^{9} / \mathrm{L}$. The PB film revealed many circulating blasts and immunophenotyping by flow cytometry was consistent with AML. He was treated with aggressive hydration, allopurinol, hydroxyurea, and red cell and platelet transfusions. Concurrent computerized tomography $(\mathrm{CT})$ of the abdomen and pelvis also detected enlarged retroperitoneal lymph nodes, a large abdominal mass, and bone metastases. A CT guided biopsy of the abdominal mass revealed low-grade follicular lymphoma. The BM evaluation confirmed the AML and also disclosed a low level of involvement by follicular lymphoma. Cytogenetic analysis of the BM specimen showed an abnormal karyotype. FISH for $\mathrm{t}(8 ; 21)(R U N X 1 / R U N X 1 T 1)$ and inv(16) (CBF $\beta)$ were normal, whereas a $4 q 12$ probe detected a rearrangement in PDGFRa. He was then given hydroxyurea, methylprednisolone and allopurinol. The patient was referred to our hospital for treatment with imatinib $(600 \mathrm{mg} /$ day) for AML and high dose methylprednisolone (1 g/day $\times 3$ days) and rituximab (375 $\mathrm{mg} / \mathrm{m}^{2}$ ) for the follicular lymphoma. After 7 days of imatinib, PB blast counts continued to increase. Therefore, therapy was changed to induction chemotherapy with cytarabine $(100 \mathrm{mg} / \mathrm{m} 2 /$ day $\times 5$ days $)$ and idarubicin $(13 \mathrm{mg} / \mathrm{m} 2 /$ day $\times 2$ days). CT imaging showed a decrease in the bulky abdominal adenopathy and splenomegaly. However, a day 15 BM evaluation showed persistent AML. Due to persistent leukemia and poor performance status the patient opted for palliative care and expired 11 months from the initial diagnosis of CMML.

\section{Materials and methods Morphology and flow cytometry}

Slides of PB films and BM aspirate smears (Wright-Giemsa stain) and BM (hematoxylin and eosin stain) were reviewed. Flow cytometry was performed at our hospital using a 4-color
FACSCalibur flow cytometry instrument with CELLQuest software (Becton Dickinson, San Jose, CA) and analyzed with Paint-A-Gate software (Becton Dickinson). BM processing and antibody staining were performed as previously described [20].

\section{Chromosome analysis and FISH study}

Whole BM was cultured for $24 \mathrm{hrs}$ in RPMI1640 supplemented with $10 \%$ fetal bovine serum, $1 \%$ L-glutamine and $1 \%$ Penstrep. These short term cultures were harvested following standard protocols. Air-dried metaphase spreads were trypsin-G-banded and karyotypes were described following ISCN 2009. FISH probes used in this study were purchased from Abbott Molecular (Des Plains, IL); these were used following the standard FISH protocol (co-denaturation of the probe and target at $74^{\circ} \mathrm{C}$ for $4 \mathrm{~min}$, hybridization over-night at $37^{\circ} \mathrm{C}$, and washing at $72^{\circ} \mathrm{C}$ for $2 \mathrm{~min}$ ). Images were captured using the Applied Spectral Imaging (Carlsbad, CA) software.

\section{Cytogenomic microarray analysis (CMA)}

Cytogenomic microarray analysis was performed with DNA extracted from bone marrow using an Agilent CGH+SNP 180k microarray platform (Agilent GGXChip+SNP v1.0 4-plex CGH) according to the manufacturer's protocol (Agilent Technologies, Santa Clara, CA). Data interpretation was performed using Genoglyphix software (Perkin Elmer, Waltham, MA). This data were deposited into NCBI GEO data base with the accession number GSE80263.

\section{Results}

\section{Morphology and flow cytometry}

The $\mathrm{BM}$ aspirate smears at the time of the diagnosis of $\mathrm{AML}$ revealed $50 \%$ myeloid blasts, an increased proportion of monocytes and maturing granulocytes, dysgranulopoiesis and dyserythropoiesis (Figures $1 \mathrm{~A}$ and $1 \mathrm{~B}$ ). The BM biopsy was $>90 \%$ cellular and also showed a focal paratrabecular infiltrate of small B-cells, which accounted $<5 \%$ of the cellularity. Flow cytometry on the PB identified $24 \%$ myeloid blasts and $32 \%$ monocytes with aberrant CD56 expression (Figure 1C) and 1.1\% kappa monotypic B-lymphoid cells (not shown). The leukemia was classified as "AML with myelodysplasia-related changes [21]." A bone marrow evaluation 14 days after induction chemotherapy was $90 \%$ cellular with persistent AML (i.e., $47 \%$ myeloblasts).

\section{Cytogenetics and FISH}

A total of 20 metaphases were evaluated from the over-night cultured cells of the BM specimen obtained at 8 months after initial diagnosis; an abnormal karyotype: $46, \mathrm{XY}, \mathrm{t}(4 ; 12 ; 6)$ (q12;p13;p21) was found in 17 metaphases (Figure 2). FISH analysis was performed with D5S721, D5S23/EGR1, D7Z1/D7S522, D8Z2/D20S108, RUNX1/RUNX1T1, PML/RARA, CBFB, FIP1L1/ PDGFR (tri-color 4q12 probe), and MLL probes. FIP1L1/PDGFRa probe showed clonal separation of PDGFRa from FIP1L1 in $78 \%$ of cells and the D8Z2 probe detected three copies in $2.5 \%$ of cells (above our cut-off limit for normal pattern); the 


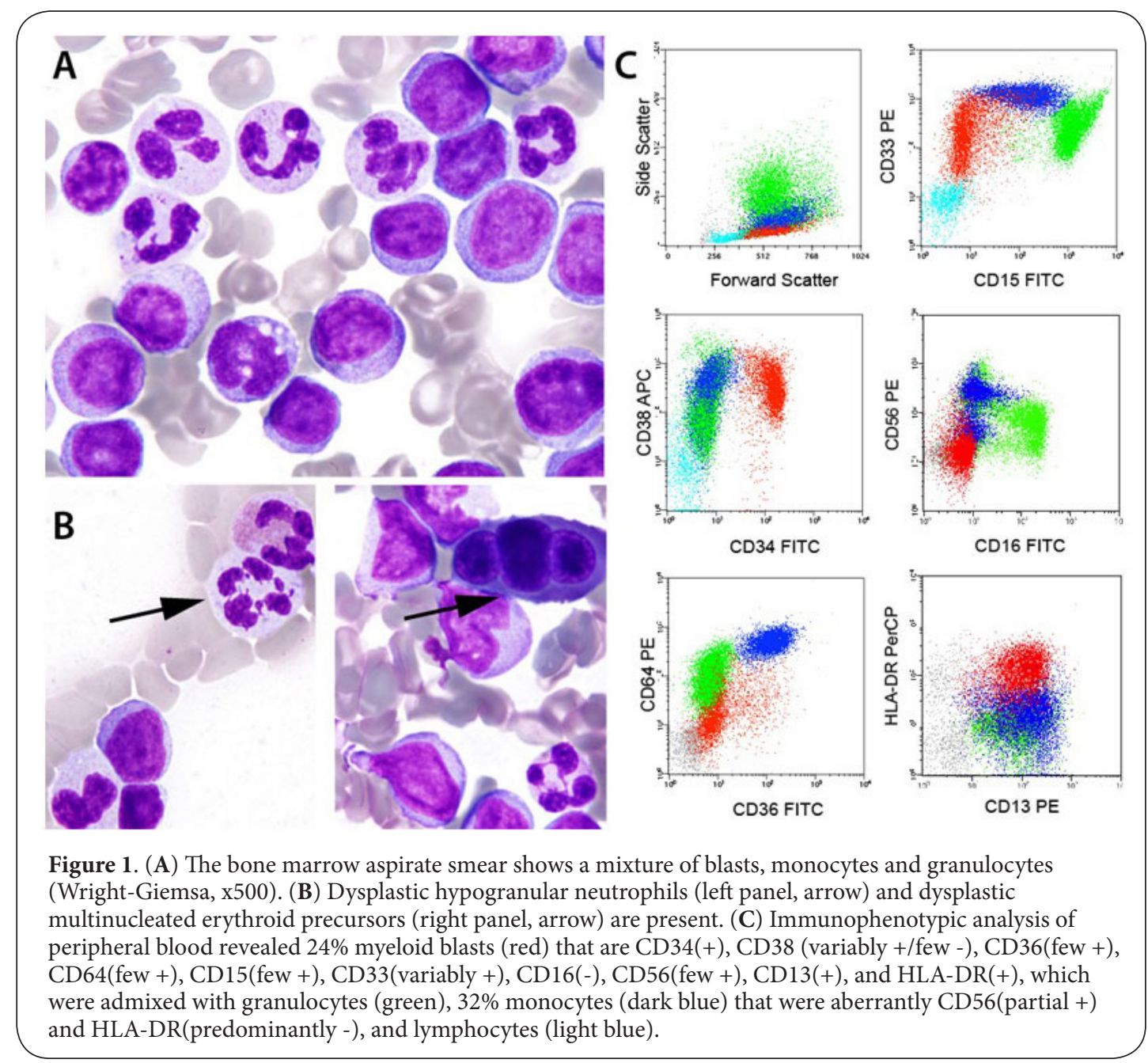

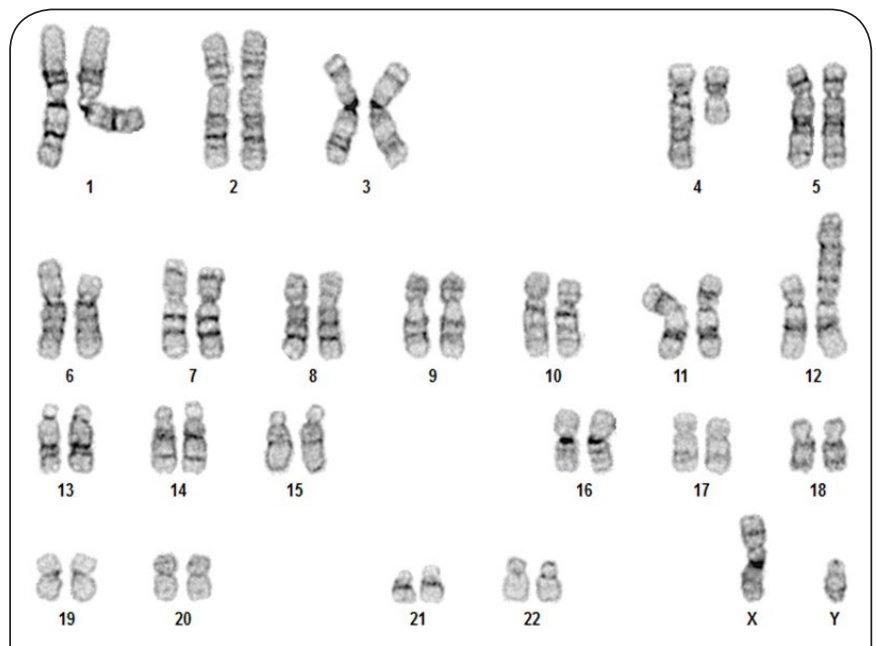

Figure 2. G-banded karyotype showing t(4;12;6)(q12;p13;p21).

latter finding suggests the presence of a minor clone with trisomy 8 which is under the limit of detection by standard cancer cytogenetic analysis of 20 metaphases. All other probes showed normal signal pattern. Since the karyotype showed a $\mathrm{t}(4 ; 12 ; 6)$ we performed FISH with ETV6 break-apart probe on $\mathrm{G}$-banded metaphases. This showed that ETV6 was rearranged and 5 -region translocated to $6 \mathrm{p} 21$. Double hybridization with $4 q 12$ probe and ETV 6 break-apart probe showed a fusion signal between PDGFRa and ETV6 at 12p13 (Figure 3). A BM specimen 14 days after induction chemotherapy had the above abnormal karyotype in 18 of the 20 metaphases evaluated.

CMA analysis of DNA extracted from the diagnostic bone marrow specimen identified four regions of copy neutral absence of heterozygosity $(\mathrm{AOH})$ with the following karyotype: arr[hg19] 6p25.2p24.3(2,518,736-10,211,449) x2 hmz,6p23p22.1(14,337,193-27,405,743)x2 hmz, 10q22.3q23.1(78,337,899-85,795,678)x2 hmz,16p13.3 $(115,072-5,794,233) \times 2 \mathrm{hmz}$. No significant copy number gain or loss was identified, indicating no loss or gain at the sites of the chromosomal breakpoints identified by the conventional cytogenetic analysis. All four of the regions of $\mathrm{AOH}$ were copy neutral. Two were present on the short arm of chromosome 6 (chr6:2518736-10211449 and chr6:14337193-27405743), one on the long arm of chromosome 10 (chr10: 78337899 - 


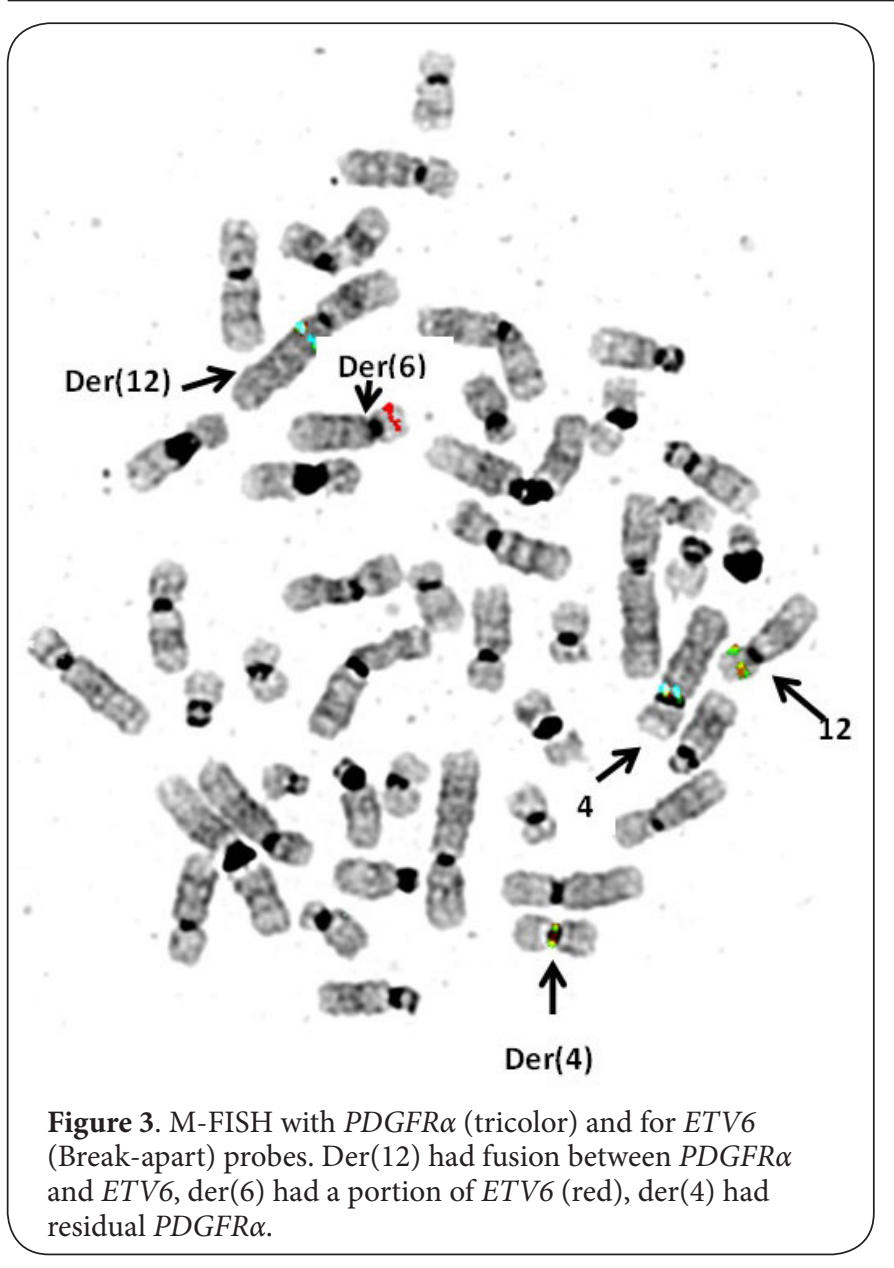

85795678) and one on the short arm of chromosome 16 (chr16: 115072-5794233).

The four regions of $\mathrm{AOH}$ in this patient encompassed over 400 genes, including $242 \mathrm{OMIM}$ genes. Evaluation of gene function for each of these genes was conducted using GeneCards encyclopedia (www.genecards.org), and annotated by the area of interest utilizing UCSC, Ensemble, Uniprot, MGI mutation, GO/KEGG pathway, OMIM diseases, and MalaCards diseases [22]. This evaluation indicated that 6 genes, E2F3, GMNN, CHTF18, TELO2, CCNF and PKMYT1 have a cell cycle function; 7 genes, TXNDC5, SOX4, PRL, AXIN1, ZNF598, NRG3 and DNAJA3 have a function related to apoptosis; 8 genes, DEK, ID4, TRIM38, ZMIZ1, IL32, CREBBP, GLIS2 and PGP have been reported to be related to established leukemic entities; and 8 genes, PKMYT1, IL32, RIPK1, PRPF4B, NRG3, MLST8, PGP and $P D P K 1$ have been linked to tyrosine kinase signaling pathways. The identification of these regions of $\mathrm{AOH}$ and their associated gene content point to the fact that homozygous aberrations in these genes may play a critical pathogenetic role in this neoplasm. Of particular interest are those genes related to tyrosine kinase signaling pathways and the fact that this particular neoplasm is known to involve constitutive activation of the tyrosine kinase domain PDGFRa of by the fusion partner. The identification of additional genes associated with tyrosine kinase signaling may ultimately provide insight into potential targeted treatment strategies.

\section{Literature data for ETV6/PDGFR $\alpha$ fusion}

A search of Mittelman's database [23] and PubMed had identified 37 cases of leukemia with a $t(4 ; 12)$ or its variant (one case) (Table 1). Among these 28 patients had AML, three had ALL, 2 had RAEB, and one each had natural killer cell leukemia, polycythemia vera, chronic eosinophilic leukemia, and an undifferentiated leukemia. There were 22 males and 12 females (M/F ratio 2), and gender not reported for three cases. Median age at diagnosis was 54 years (range 3 to 82). Cytogenetically the karyotype was pseudo-diploid with the karyotype $t(4 ; 12)$ in 19 patients; in the remaining 18 patients the karyotype had at least one additional abnormality. All patients had combination chemotherapy (regimen varied) at diagnosis. Survival data were reported for 21 patients; 10 patients deceased ( 7 males, 3 females) at a median survival of 5.5 months (range $<1$ to 96 months); one of these was treated with imatinib after identifying ETV6/PDGFRa fusion, but had no response [24]. Eleven patients (7 males, 4 females) were alive at a median follow up of 19 months (range 3 to 93 months); one of these was treated with imatinib after identifying ETV6/ PDGFRa fusion [25]. Four other patients were alive after bone marrow transplantation (BMT). Among 25 adult patients with $A M L$, survival data were available for 16 patients; eight were alive at a median follow up of 19 months, and eight deceased (median survival 4 months); two other patients are alive after BMT. Among the eight alive six ( $85.7 \%$ ) had pseudo-diploid karyotype and two had additional abnormalities; among the eight deceased five (62.5\%) had pseudo-diploid karyotype and three had additional abnormalities; however this difference is not significant ( $p-0.57)$.

\section{Discussion}

This is the first case of AML with a three way translocation, $\mathrm{t}(4 ; 12 ; 6)$ that created a fusion gene between PDGFRa and ETV6. The patient did not respond to treatment with imatinib or induction chemotherapy. Receptor tyrosine kinases $P D G F R a$, PDGFR $\beta$ and FGFR 1 have been deregulated by the formation of fusion genes, and these are implicated in the pathogenesis of myeloid and lymphoid neoplasms with clonal eosinophilia. Genetic alteration affecting PDGFRa most commonly presents as MPN, but also has been rarely reported in AML, and in precursor T-lymphoblastic leukemia with clonal eosinophilia. In myeloid and lymphoid neoplasms with eosinophilia one of the typical cytogenetic alterations is cryptic deletion at $4 q 12$; this fuses FIP1L1 with PDGFRa $[\mathbf{8 , 2 6 ]}$. Other rare cytogenetic abnormalities involving PDGFRa reported in hematolymphoid neoplasms include $t(4 ; 22)(q 12 ; q 11)$, ins $(9 ; 4)(q 33 ; q 12 q 25), t(2 ; 4)$ (p24;q12) and $t(4 ; 12)(q 12 ; p 13)[27-30]$. These patients respond well to treatment with imatinib $[8,31,32]$. Furthermore, a few longitudinal studies have shown a close association with the 
Koduru et al. Hematology and Leukemia 2016,

http://www.hoajonline.com/journals/pdf/2052-434X-4-1.pdf

doi: $10.7243 / 2052-434 X-4-1$

Table 1. Clinical and cytogenetic features of patients with PDGFRA/ETV6 fusion.

\begin{tabular}{|c|c|c|c|c|c|c|c|c|}
\hline Age/Gender & Initial DX & Initial Tx & Later Dx & Karyotype & FISH & $\mathbf{T x}$ & $\begin{array}{l}\text { Survival } \\
(\mathrm{M})\end{array}$ & Reference \\
\hline $77 / \mathrm{F}$ & AUL & NA & None & $46, \mathrm{XX}, \mathrm{t}(4 ; 12)(\mathrm{q} 12 ; \mathrm{p} 13)$ & ND & NA & NA & {$[60]$} \\
\hline $64 / \mathrm{M}$ & AML & FCR & AML & $46, \mathrm{XY}, \mathrm{t}(4 ; 12)(\mathrm{q} 12 ; \mathrm{p} 13), \operatorname{del}(5)(\mathrm{q} 35)$ & ND & $\begin{array}{l}\text { FCR, } \\
\text { Imatinib/ } \\
\text { Gemtuzumab }\end{array}$ & $\begin{array}{l}\text { No } \\
\text { response }\end{array}$ & {$[24]$} \\
\hline $74 / \mathrm{F}$ & AML M1 & NA & None & $\begin{array}{l}\text { 46,XX,del(10)(q11), t(4;12) } \\
(\mathrm{q} 13 ; \mathrm{p} 13)\end{array}$ & ND & None & NA & {$[61]$} \\
\hline $33 \mathrm{Y} \mathrm{M}$ & AML & Dauno+AraC & None & $46, \mathrm{XY}, \mathrm{t}(4 ; 12)(\mathrm{q} 11 ; \mathrm{p} 13)$ & ND & None & $1 \mathrm{M}$ & {$[62]$} \\
\hline $29 / \mathrm{M}$ & RAEB & NA & None & $46, \mathrm{XY}, \mathrm{t}(4 ; 12)(\mathrm{q} 12 ; \mathrm{p} 13)$ & & None & LostF/U & {$[63]$} \\
\hline $76 / \mathrm{F}$ & NK-cell & Chemo & None & $46, \mathrm{XX}, \mathrm{t}(4 ; 12)(\mathrm{q} 12 ; \mathrm{p} 13)$ & ND & None & $8+$ & {$[38]$} \\
\hline $70 / \mathrm{M}$ & AML M0 & Chemo & None & $\begin{array}{l}\text { 46,XY,t(4;12)(q12;p13) } \\
47, \operatorname{idem},+\operatorname{del}(1)(\mathrm{p} 11 \mathrm{p} 35)\end{array}$ & ND & None & $<1 \mathrm{M}$ & {$[38]$} \\
\hline $81 / \mathrm{M}$ & AML M0 & Chemo & None & $\begin{array}{l}\text { 46,XY,t(4;12)(q12;p13)/ } \\
\text { 46,idem,del(5)(q13q33) }\end{array}$ & ND & None & $3+$ & {$[38]$} \\
\hline $54 / \mathrm{M}$ & AML M0 & Chemo & None & $46, \mathrm{XY}, \mathrm{t}(4 ; 12)(\mathrm{q} 12 ; \mathrm{p} 13)$ & ND & BMT & $50+$ & {$[38]$} \\
\hline $25 / \mathrm{M}$ & tAML & Chemo & None & $46, \mathrm{XY}, \mathrm{t}(4 ; 12)(\mathrm{q} 12 ; \mathrm{p} 13)$ & ND & None & 12 & [39] \\
\hline $51 / \mathrm{M}$ & MPD & $\begin{array}{l}\text { Hydroxy } \\
\text { carbomide }\end{array}$ & None & $46, \mathrm{XY}, \mathrm{t}(4 ; 12)(\mathrm{q} 2 ? 3 ; \mathrm{p} 1 ? 2)$ & ND & Imatinib & $93+$ & {$[25]$} \\
\hline $42 / \mathrm{F}$ & AML-M2 & NA & None & $46, \mathrm{XX}, \mathrm{t}(4 ; 12)(\mathrm{q} 12 ; \mathrm{p} 12-13)$ & ND & NA & $13.3 \mathrm{M}$ & {$[64]$} \\
\hline $3 / \mathrm{M}$ & ALL-L1 & NA & NA & $\begin{array}{l}\text { 47,XY,t(4;12)(q13;p12), } \\
\operatorname{del}(1 \mathrm{q}), \operatorname{del}(2 \mathrm{q}), \operatorname{der}(3 \mathrm{q}) \operatorname{del}(6) \\
(\mathrm{q} 21 \mathrm{q} 25),+ \text { mar }\end{array}$ & ND & NA & NA & {$[65]$} \\
\hline $4 / \mathrm{M}$ & ALL-L1 & NA & NA & $\begin{array}{l}46, \mathrm{XY}, \mathrm{t}(4 ; 12)(\mathrm{q} 13 ; \mathrm{p} 12) \\
\operatorname{der}(1) \mathrm{t}(1 ; ?)(\mathrm{p} 36 ; ?)\end{array}$ & ND & NA & NA & {$[65]$} \\
\hline $70 / \mathrm{F}$ & $\mathrm{t}-\mathrm{AML}$ & NA & None & $\begin{array}{l}\text { 46,XX,del(7)(q32q36)/47,idem,+2/ } \\
\text { 47,idem, } \mathrm{t}(4 ; 12)(\mathrm{q} 12 ; \mathrm{p} 13),+21\end{array}$ & $\begin{array}{l}\text { PDGFR } \alpha / \\
\text { ETV6 }\end{array}$ & NA & NA & {$[14]$} \\
\hline $41 / \mathrm{M}$ & AML M0 & Chemo & None & $\begin{array}{l}\text { 46,XY,t }(2 ; 4 ; 12)(\mathrm{p} 21 ; \mathrm{q} 12 ; \mathrm{p} 13) /+3 \\
\text { clones }\end{array}$ & + & None & $3 \mathrm{M}$ & {$[41]$} \\
\hline $61 / \mathrm{M}$ & AML M2 & Chemo & None & $46, \mathrm{XY}, \mathrm{t}(4 ; 12)(\mathrm{q} 11-12, \mathrm{p} 13)$ & ND & None & $19+$ & {$[66]$} \\
\hline $43 / \mathrm{M}$ & AML M0 & Chemo & None & $46, \mathrm{XY}, \mathrm{t}(4 ; 12)(\mathrm{q} 11-12 ; \mathrm{p} 13)$ & ND & None & $31+$ & {$[66]$} \\
\hline $49 / \mathrm{M}$ & AML M2 & Chemo & None & $46, \mathrm{XY}, \mathrm{t}(4 ; 12)(\mathrm{q} 11-12 ; \mathrm{p} 13)$ & ND & None & $6+$ & {$[66]$} \\
\hline $57 / \mathrm{M}$ & AML-M5 & Chemo & None & $46, \mathrm{XY}, \mathrm{t}(4 ; 12)(\mathrm{q} 12 ; \mathrm{p} 13)$ & $\begin{array}{l}\text { PDGFR } \alpha / \\
\text { ETV6 }\end{array}$ & None & $24+$ & {$[42]$} \\
\hline NA & AML & NA & Relapse & $46, \mathrm{XY}, \mathrm{t}(4 ; 12)(\mathrm{q} 11 ; \mathrm{p} 13)$ & ND & None & NA & [67] \\
\hline $39 / \mathrm{F}$ & AML M1 & HAM/HAM & None & $\begin{array}{l}45, \mathrm{XX}, \mathrm{t}(4 ; 12)(\mathrm{q} 12 ; \mathrm{p} 13) \operatorname{dic}(7 ; 12) \\
(\mathrm{q} 11 ; \mathrm{p} 13)\end{array}$ & $\begin{array}{l}\text { CHIC2/ } \\
\text { ETV6 }\end{array}$ & Chemo Aive & BMT & {$[68]$} \\
\hline $70 / \mathrm{M}$ & AML M0 & Chemo & None & $46, \mathrm{XY}, \mathrm{t}(4 ; 12)(\mathrm{q} 13 ; \mathrm{p} 13)$ & ND & None & $5 \mathrm{M}$ & [69] \\
\hline $18 / \mathrm{F}$ & AML M2 & Chemo & NA & $46, \mathrm{XX}, \mathrm{t}(4 ; 12)(\mathrm{q} 12 ; \mathrm{p} 13)$ & ND & None & $9+, \mathrm{BMT}$ & {$[70]$} \\
\hline $67 / \mathrm{M}$ & $\begin{array}{l}\text { MDS/ } \\
\text { RAEBt }\end{array}$ & Chemo & None & $\begin{array}{l}45, \mathrm{XY},-5,-7,+ \text { mar/42-43 idem,-11,- } \\
\text { 17,+der(?)hsr(11)(q23)/43,idem } \\
\mathrm{t}(4 ; 12)(\mathrm{q} 12 ; \mathrm{p} 13)\end{array}$ & ND & None & $6 \mathrm{M}$ & {$[71]$} \\
\hline $14 / \mathrm{F}$ & AML M2 & Chemo & NA & $46, \mathrm{XX}, \mathrm{t}(4 ; 12)(\mathrm{q} 12 ; \mathrm{p} 13), \mathrm{i}(17)(\mathrm{q} 10)$ & TEL+ & NA & $9+$ & {$[72]$} \\
\hline $47 / \mathrm{F}$ & PV & Busulfan & AML M4 & $46, \mathrm{XY}, \mathrm{t}(4 ; 12)(\mathrm{q} 12 ; \mathrm{p} 13)$ & ND & Chemo & $96 \mathrm{M}$ & {$[73]$} \\
\hline $47 / \mathrm{M}$ & AML M2 & & NA & $46, \mathrm{XY}, \mathrm{t}(4 ; 12)(\mathrm{q} 12 ; \mathrm{p} 13)$ & ETV6+ & NA & NA & {$[45]$} \\
\hline $69 \mathrm{M}$ & AML M0 & & & $\begin{array}{l}\text { 46,XY,t(4;12)(q12;p13)/46, idem,- } \\
\text { 7,+11/46,idem, del(7)(q21) }\end{array}$ & ETV6+ & NA & NA & {$[45]$} \\
\hline $59 / \mathrm{M}$ & AML M7 & NA & NA & $46, \mathrm{XY}, \mathrm{t}(4 ; 12)(\mathrm{q} 12 ; \mathrm{p} 13)$ & NA & NA & $2.5 \mathrm{M}$ & {$[74]$} \\
\hline $46 / \mathrm{M}$ & AML M4 & & & $\begin{array}{l}\text { 46,XY,t(4;12)(q12;p13),- } \\
7,+6 / 46, X Y, t(4 ; 12), \operatorname{del}(9 q)\end{array}$ & NA & NA & NA & {$[75]$} \\
\hline $11 / \mathrm{F}$ & ALL & ALL8 & None & $\begin{array}{l}\text { 45,XX,t(4;12)(q13?;p12), } \\
\operatorname{der}(7), \operatorname{der}(21)\end{array}$ & None & None & $24+$ & {$[76]$} \\
\hline Peds/F & AML M1 & NA & NA & $\begin{array}{l}46, \mathrm{XX},-7, \operatorname{inv}(3)(\mathrm{p} 25 \mathrm{q} 21), \operatorname{del}(6) \\
\mathrm{q} 13 \mathrm{q} 21), \operatorname{del}(10)(\mathrm{q} 24), \mathrm{t}(4 ; 12) \\
(\mathrm{q} 12 ; \mathrm{q} 13),+\operatorname{mar} / 47, \mathrm{XX}, \mathrm{idem},+15\end{array}$ & ND & NA & NA & {$[77]$} \\
\hline
\end{tabular}


Koduru et al. Hematology and Leukemia 2016,

http://www.hoajonline.com/journals/pdf/2052-434X-4-1.pdf

doi: $10.7243 / 2052-434 X-4-1$

Continuation of table 1.

\begin{tabular}{|c|c|c|c|c|c|c|c|c|}
\hline $\begin{array}{l}\text { Age/ } \\
\text { Gender }\end{array}$ & Initial DX & Initial $\mathbf{T x}$ & Later Dx & Karyotype & FISH & $\mathbf{T x}$ & $\begin{array}{l}\text { Survival } \\
(\mathrm{M})\end{array}$ & Reference \\
\hline $82 / \mathrm{M}$ & AML M1 & NA & None & $4, \mathrm{XY}, \mathrm{t}(4 ; 12)(\mathrm{q} 11 ; \mathrm{p} 13)$ & None & None & NA & {$[37]$} \\
\hline $67 / \mathrm{NA}$ & AML-M0 & NA & None & $\begin{array}{l}\text { 47,XY,t(4;12)(q12;p13),-21, } \\
+\operatorname{der}(21) \operatorname{del}(\mathrm{q} ?) \mathrm{x} 2\end{array}$ & ND & NA & NA & [19] \\
\hline 64/NA & AML-M0 & NA & None & $46, \mathrm{XY}, \mathrm{t}(4 ; 12)(\mathrm{q} 12 ; \mathrm{p} 13)$ & ND & NA & NA & {$[19]$} \\
\hline $66 / \mathrm{F}$ & tAML-M1 & NA & NA & $\begin{array}{l}46, \mathrm{XX}, \mathrm{t}(4 ; 12)(\mathrm{q} 12 ; \mathrm{p} 13) / \\
46, \text { idem,i(17)(q10) }\end{array}$ & ND & NA & 16 & {$[78]$} \\
\hline
\end{tabular}

development of clonal eosinophilia during the course of leukemia and response to treatment with imatinib. Zota et al., [33] reported a case of CMML in which a clone with FIP1L1/PDGFRa fusion transiently developed with concurrent $\mathrm{PB}$ and $\mathrm{BM}$ eosinophilia and regressed with imatinib treatment, whereas the initial CMML clone persisted and led to fatality. Shah et al., [34] reported the development of FIP1L1/PDGFRa fusion during transformation to AML associated with eosinophilia in a patient with an initial diagnosis of CMML that harbored trisomy 8. Similar fusion was reported in five patients with AML and eosinophilia; all these patients have responded positively to imatinib [7]. Sorour et al., [35] reported an AML patient with complex karyotype who responded to chemotherapy. However, the patient developed increasing eosinophilia; at this time BM was positive for FIP1L1/PDGFRa fusion. Patient responded well to imatinib, had allogenic BMT, relapsed with a D842V kinase resistant mutation in FIP1L1/PDGFRa domain and expired 15 months post BMT. PDGFRa abnormalities have not been reported in CMML without eosinophilia.

ETV6 rearrangements in myeloid disorders are reported at a frequency of $0.5 \%$; in $\mathrm{AML}$ it was detected at a frequency of $1.1 \%$, but not in non-eosinophilic CMML [14]. Among the different translocation partners of $12 p 13, t(4 ; 12)(q 12 ; p 13)$ is a recurring abnormality in adult AML with an incidence of $0.6 \%$ [36]. A review of the current literature identified 37 cases with a $t(4 ; 12)$ with a male to female ratio of $2: 1$. These tumors have common characteristics that include dysplasia of three hematopoietic lineages, pseudolymphoid morphology, absent or low myeloperoxidase activity, preservation of the platelet count, and megakaryocytes in BM [36]. Blast cells have been reported to be positive for CD7, CD13, CD33, CD34 and HLA-DR, suggesting that the leukemic cells have an immature myeloid stem cell origin [37].

Molecular structure of the cytogenetically identified $t(4 ; 12)$ (q11-12;p13) is heterogeneous. Cools et al., [38] reported four cases in which the $t(4 ; 12)(q 12 ; p 13)$ fused $B T L(C H I C 2)$ at $4 q 12$ to ETV6 at 12p13, resulting in the expression of a hybrid BTL/ ETV6 transcript. Cools et al., [39] reported another case of AML with a $t(4 ; 12)$ in which $G S H 2$, an another gene telomeric to CHIC2 at 4q12, fused with ETV6. Silva et al., [19] identified ETV6 translocations not resulting in a fusion protein in two cases, but identified loss of ETV6 by deletion, and heterozygous or homozygous mutations in the ETV6 gene in AML. Therefore they suggested that haplo-insufficiency of ETV6 as a leukemogenic step in these leukemias. Yoshida et al., [40] reported an MPN with eosinophilia in which ETV6 was fused with the C-terminus of PDGFRa.

Clonal genetic changes in ETV6 have different clinical outcomes in leukemia. In pediatric ALL ETV6 is fused with RUNX1 in a cryptic $t(12 ; 21)$, and these patients have good prognosis; whereas ETV6 rearrangements in AML are considered as having intermediate prognosis [14]. The survival data on AML patients with a $t(4 ; 12)$ also indicate inferior outcome with combination chemotherapy and a median survival of 4 months in about $55 \%$ of patients.

To the best of our knowledge, this is the first case of a threeway translocation $\mathrm{t}(4 ; 12 ; 6)$ involving PDGFR $a$ and ETV6 genes that developed during transformation from $C M M L$ to an $A M L$ without eosinophilia. Hamaguchi et al., [41] reported a threeway translocation, $\mathrm{t}(2 ; 4 ; 12)(\mathrm{p} 21 ; \mathrm{q} 12 ; \mathrm{p} 13)$ in a $41 \mathrm{Y}$ male with a diagnosis of AML-MO; but the involvement of PDGFRa was not determined and ETV6 was not rearranged. The patient had no response to combination chemotherapy and expired 3 months from diagnosis. Al-Kali et al., [24] reported one case of AML with $\mathrm{t}(4 ; 12)$ and did not responsive to imatinib treatment. Heaton et a [42] reported ETV6 /PDGFRa fusion by FISH in AML-M5 with karyotype $t(4 ; 12)$; complete remission was achieved with Idarubicin+Ara-c (3+7) regimen.

Survival of patients with ETV6/PDGFRa fusion appears to be different from FIP1L1/PDGFRa fusion in patients. This may have been due to different molecular structure of the fusion gene. In the PDGFRa the WW domain has inhibitory role [43], and its disruption by fusion with other genes is the key molecular mechanism of constitutive tyrosine kinase activity in these disorders [44]. In fact the WW domain was invariably disrupted in cases of MPN with eosinophilia and FIP1L1/PDGFRa fusion; these patients had constitutive tyrosine kinase activity and responded well to imatinib. An alternative mechanism of activation of tyrosine kinase activation of PDGFRa was detected in an AML patient with $\mathrm{t}(4 ; 12)$ [25]. In this patient ETV6 was fused to the N-terminus of PDGFRa and it had overridden the inhibitory effect of the intact WW domain in PDGFRa. In these instances kinase activity is obtained through oligomerization mediated by the fusion partner [25]. Molecular structure of 
Koduru et al. Hematology and Leukemia 2016,

the fusion between in PDGFRa and ETV6 was examined in a few cases of $t(4 ; 12)$. Curtis et al., [22] reported an MPN with eosinophilia and $t(4 ; 12)$ in which ETV6 was translocated to the 5 '-of an intact WW domain of PDGFRa; this patient responded to imatinib. Yoshida et al., [40] reported an another case in which ETV6 fused to the C-terminus of PDGFRa and the patient did not respond to imatinib. Therefore, it is possible that in the current patient the WW domain in PDGFRa was intact and the fusion of DNA from chromosome 6p23 region may have been on the C-terminus of PDGFRa. This molecular configuration does not lead to increased tyrosine kinase activity in PDGFRa, and therefore the patient did not respond to imatinib. Thus molecular characterization of PDGFRa fusion genes is important in determining whether imatinib is a suitable agent in the management of these patients.

A $t(6 ; 12)(p 21 ; p 13)$ have been described in seven cases of different lymphoid malignancies [23,45-50]. Among these, ETV6 rearrangement was confirmed by FISH in three $[26,45,46]$, but the fusion partner was not identified. In a case of RAEB-1 with ins(6;12)(p22;p13) ETV6 was fused with KIAA0319 at 6p22 [51]. The ETV6 probe used in this study was a break-apart probe; red signal covered the $5^{\prime}$-region whereas the green signal covered the genome beginning the 3 '-end of the gene. FISH signal pattern on the abnormal metaphases showed a split in the red signal with a residual red signal on the der(12) and the split signal on the der(6p). Although the DNA at 6p21 that partnered in fusion with the 5'-region of ETV6 was not identified, it is possible that the putative gene at $6 \mathrm{p} 21$ was deregulated. A number of genes have been mapped to the band 6p21; these genes include FOXp4, TAF8, and CCND3. Among these, constitutive activation of CCND3 in different B-cell neoplasms has been well established $[52,53]$. In a case of chronic lymphocytic leukemia with $\mathrm{t}(6 ; 12)(\mathrm{p} 21 ; \mathrm{p} 13)$ the ETV6 gene was rearranged with a break in between exon 1 and exon 2, but the break at 6p21 was not molecularly defined [46]. In the current patient the three-way translocation may have led to three somatic oncogenic changes affecting PDGFRa, ETV6 and possibly CCND3, or another gene at the breakpoint at 6p21.

Loss of genetic material acting as a leukemogenic event was excluded in this patient by CMA. No significant copy number loss or gain of chromosomal regions was identified. However, we observed four copy neutral regions of $\mathrm{AOH}$ with gene content. Copy neutral $\mathrm{AOH}$ may originate through segmental uniparental disomy which in turn leads to homozygosity for functionally relevant gene mutations in the tumor genome; this constitutes an important driving force in cancer [54]. Copy neutral AOH has been seen in about 20\% AMLs [55-57] and these included $6 p, 6 q$ and on $16 q[\mathbf{5 8}, \mathbf{5 9}]$. Although additional specific genes critical to the tumorigenesis of this neoplasm have not been established, it is possible that homozygosity for one or more genes in these regions impacted the biological behavior of the leukemia cells.

\section{Competing interests}

The authors declare that they have no competing interests.

Authors' contributions

\begin{tabular}{|l|c|c|c|c|c|c|}
\hline Authors' contributions & PK & NG & PP & JW & KW & SM \\
\hline Research concept and design & $\checkmark$ & -- & -- & -- & -- & -- \\
\hline Collection and/or assembly of data & -- & -- & $\checkmark$ & $\checkmark$ & $\checkmark$ & $\checkmark$ \\
\hline Data analysis and interpretation & -- & $\checkmark$ & -- & $\checkmark$ & $\checkmark$ & $\checkmark$ \\
\hline Writing the article & $\checkmark$ & -- & -- & -- & $\checkmark$ & $\checkmark$ \\
\hline Critical revision of the article & $\checkmark$ & -- & $\checkmark$ & & $\checkmark$ & $\checkmark$ \\
\hline Final approval of article & $\checkmark$ & $\checkmark$ & $\checkmark$ & $\checkmark$ & $\checkmark$ & $\checkmark$ \\
\hline Statistical analysis & -- & -- & -- & -- & -- & -- \\
\hline
\end{tabular}

Publication history

EIC: Evangelos Terpos, University of Athens School of Medicine, Greece. Received: 02-Mar-2016 Final Revised: 18-Apr-2016

Accepted: 11-May-2016 Published: 17-May-2016

\section{References}

1. Vardiman JW, Thiele J, Arber DA, Brunning RD, Borowitz MJ, Porwit A, Harris NL, Le Beau MM, Hellstrom-Lindberg E, Tefferi A and Bloomfield CD. The $\mathbf{2 0 0 8}$ revision of the World Health Organization (WHO) classification of myeloid neoplasms and acute leukemia: rationale and important changes. Blood. 2009; 114:937-51. | Article I PubMed

2. Parikh SA and Tefferi A. Chronic myelomonocytic leukemia: 2012 update on diagnosis, risk stratification, and management. Am J Hematol. 2012; 87:610-9. | Article | PubMed

3. Onida F, Kantarjian HM, Smith TL, Ball G, Keating MJ, Estey EH, Glassman $\mathrm{AB}$, Albitar M, Kwari MI and Beran M. Prognostic factors and scoring systems in chronic myelomonocytic leukemia: a retrospective analysis of 213 patients. Blood. 2002; 99:840-9. I Article I PubMed

4. Bacher U, Haferlach T, Kern W, Hiddemann W, Schnittger S and Schoch C. Conventional cytogenetics of myeloproliferative diseases other than CML contribute valid information. Ann Hematol. 2005; 84:250-7. | Article I PubMed

5. Haase D, Germing U, Schanz J, Pfeilstocker M, Nosslinger T, Hildebrandt B, Kundgen A, Lubbert M, Kunzmann R, Giagounidis AA, Aul C, Trumper L, Krieger O, Stauder R, Muller TH, Wimazal F, Valent P, Fonatsch C and Steidl C. New insights into the prognostic impact of the karyotype in MDS and correlation with subtypes: evidence from a core dataset of 2124 patients. Blood. 2007; 110:4385-95. | Article | PubMed

6. Wassie EA, Itzykson R, Lasho TL, Kosmider O, Finke CM, Hanson CA, Ketterling RP, Solary E, Tefferi A and Patnaik MM. Molecular and prognostic correlates of cytogenetic abnormalities in chronic myelomonocytic leukemia: a Mayo Clinic-French Consortium Study. Am J Hematol. 2014; 89:1111-5. | Article | PubMed

7. Metzgeroth G, Walz C, Score J, Siebert R, Schnittger S, Haferlach C, Popp $H$, Haferlach T, Erben P, Mix J, Muller MC, Beneke H, Muller L, Del Valle F, Aulitzky WE, Wittkowsky $G$ and Schmitz N. Recurrent finding of the FIP1L1-PDGFRA fusion gene in eosinophilia-associated acute myeloid leukemia and lymphoblastic T-cell lymphoma. Leukemia. 2007; 21:11838. | Article | PubMed

8. Cools J, DeAngelo DJ, Gotlib J, Stover EH, Legare RD, Cortes J, Kutok J, Clark J, Galinsky I and Griffin JD et al. A tyrosine kinase created by fusion of the PDGFRA and FIP1L1 genes as a therapeutic target of imatinib in idiopathic hypereosinophilic syndrome. N Engl J Med. 2003; 348:120114. | Article | PubMed

9. Pardanani A, Ketterling RP, Li CY, Patnaik MM, Wolanskyj AP, Elliott MA Camoriano JK, Butterfield JH, Dewald GW and Tefferi A. FIP1L1-PDGFRA in eosinophilic disorders: prevalence in routine clinical practice, longterm experience with imatinib therapy, and a critical review of the literature. Leuk Res. 2006; 30:965-70. | Article | PubMed

10. Chen D, Bachanova V, Ketterling RP, Begna KH, Hanson CA and Viswanatha DS. A case of nonleukemic myeloid sarcoma with FIP1L1- 
Koduru et al. Hematology and Leukemia 2016,

http://www.hoajonline.com/journals/pdf/2052-434X-4-1.pdf

doi: $10.7243 / 2052-434 \mathrm{X}-4-1$

PDGFRA rearrangement: an unusual presentation of a rare disease. $\mathrm{Am}$ J Surg Pathol. 2013; 37:147-51. | Article | PubMed

11. Jain N, Khoury JD, Pemmaraju N, Kollipara P, Kantarjian H and Verstovsek S. Imatinib therapy in a patient with suspected chronic neutrophilic leukemia and FIP1L1-PDGFRA rearrangement. Blood. 2013; 122:3387-8. | Article | PubMed

12. Seth A, Ascione R, Fisher RJ, Mavrothalassitis GJ, Bhat NK and Papas TS. The ets gene family. Cell Growth Differ. 1992; 3:327-34. | Article | PubMed

13. Wang LC, Swat W, Fujiwara Y, Davidson L, Visvader J, Kuo F, Alt FW, Gilliland DG, Golub TR and Orkin SH. The TEL/ETV6 gene is required specifically for hematopoiesis in the bone marrow. Genes Dev. 1998; 12:2392-402. | Article | PubMed Abstract | PubMed FullText

14. De Braekeleer E, Douet-Guilbert N, Morel F, Le Bris MJ, Basinko A and De Braekeleer M. ETV6 fusion genes in hematological malignancies: a review. Leuk Res. 2012; 36:945-61. I Article | PubMed

15. Haferlach C, Bacher U, Schnittger S, Alpermann T, Zenger M, Kern W and Haferlach T. ETV6 rearrangements are recurrent in myeloid malignancies and are frequently associated with other genetic events. Genes Chromosomes Cancer. 2012; 51:328-37. I Article I PubMed

16. Al Achkar W, Aljapawe A, Liehr T and Wafa A. De novo acute myeloid leukemia subtype-M4 with initial trisomy 8 and later acquired $t(3 ; 12)$ (q26;p12) leading to ETV6/MDS1/EVI1 fusion transcript expression: A case report. Onc Letters. 2014; 7:787-790. | Article

17. Bohlander SK. ETV6: a versatile player in leukemogenesis. Semin Cancer Biol. 2005; 15:162-74. | Article | PubMed

18. Barjesteh van Waalwijk van Doorn-Khosrovani S, Spensberger D, de Knegt $\mathrm{Y}$, Tang M, Lowenberg B and Delwel R. Somatic heterozygous mutations in ETV6 (TEL) and frequent absence of ETV6 protein in acute myeloid leukemia. Oncogene. 2005; 24:4129-37. | Article | PubMed

19. Silva FPG, Morolli B and Storlazzi CT et al. ETV6 mutations and loss in AML-M10. Leukemia. 2008; 22:1639-1643.

20. Karandikar NJ, Aquino DB, McKenna RW and Kroft SH. Transient myeloproliferative disorder and acute myeloid leukemia in Down syndrome. An immunophenotypic analysis. Am J Clin Pathol. 2001; 116:204-10. | Article | PubMed

21. Swerdlow SH, Campo E and Harris NL et al. WHO Classification of Haematopoietic and Lymphoid Tissues. Eds IARC Press, Lyon. 2008.

22. Olender T, Safran $M$ and Edgar R et al. An overview of synergistic data tools for biological scrutiny. Isr J Chem. 2013; 53:185-198. | Article

23. Mittelman's data base. 2015. | Website

24. Al-Kali A, Cherry M, Kimmell K, Holter J, Kern W, Gehrs B, Ozer H and Selby $\mathrm{G}$. A case of acute myeloid leukemia initially treated as chronic lymphocytic leukemia: what do we know about t(4;12)(q12;p13)? Cancer Genet Cytogenet. 2010; 203:348-51. | Article I PubMed

25. Curtis CE, Grand FH, Musto P, Clark A, Murphy J, Perla G, Minervini MM, Stewart J, Reiter A and Cross NC. Two novel imatinib-responsive PDGFRA fusion genes in chronic eosinophilic leukaemia. Br J Haematol. 2007; 138:77-81. | Article | PubMed

26. La Starza R, Specchia G, Cuneo A, Beacci D, Nozzoli C, Luciano L, Aventin A, Sambani C, Testoni N, Foppoli M, Invernizzi R, Marynen P, Martelli MF and Mecucci $C$. The hypereosinophilic syndrome: fluorescence in situ hybridization detects the del(4)(q12)-FIP1L1/PDGFRA but not genomic rearrangements of other tyrosine kinases. Haematologica. 2005; 90:596-601. | Article | PubMed

27. Baxter EJ, Hochhaus A, Bolufer P, Reiter A, Fernandez JM, Senent L, Cervera J, Moscardo F, Sanz MA and Cross NC. The t(4;22)(q12;q11) in atypical chronic myeloid leukaemia fuses BCR to PDGFRA. Hum Mol Genet. 2002; 11:1391-7. | Article | PubMed

28. Score J, Curtis C, Waghorn K, Stalder M, Jotterand M, Grand FH and Cross NC. Identification of a novel imatinib responsive KIF5B-PDGFRA fusion gene following screening for PDGFRA overexpression in patients with hypereosinophilia. Leukemia. 2006; 20:827-32. | Article | PubMed

29. Walz C, Curtis C, Schnittger S, Schultheis B, Metzgeroth G, Schoch C, Lengfelder E, Erben P, Muller MC, Haferlach T, Hochhaus A, Hehlmann $\mathrm{R}$, Cross NC and Reiter A. Transient response to imatinib in a chronic eosinophilic leukemia associated with ins(9;4)(q33;q12q25) and a CDK5RAP2-PDGFRA fusion gene. Genes Chromosomes Cancer. 2006; 45:950-6. | Article | PubMed

30. Savage N, George TI and Gotlib J. Myeloid neoplasms associated with eosinophilia and rearrangement of PDGFRA, PDGFRB, and FGFR1: a review. Int J Lab Hematol. 2013; 35:491-500. | Article | PubMed

31. von Bubnoff N, Sandherr M, Schlimok G, Andreesen R, Peschel C and Duyster J. Myeloid blast crisis evolving during imatinib treatment of an FIP1L1-PDGFR alpha-positive chronic myeloproliferative disease with prominent eosinophilia. Leukemia. 2005; 19:286-7. | Article | PubMed

32. Barraco D, Carobolante F, Candoni A, Simeone E, Piccaluga P, Tabanelli $\mathrm{V}$ and Fanin R. Complete and long-lasting cytologic and molecular remission of FIP1L1-PDGFRA-positive acute eosinophil myeloid leukaemia, treated with low-dose imatinib monotherapy. Eur J Haematol. 2014; 92:541-5. | Article | PubMed

33. Zota V, Miron PM, Woda BA, Raza A and Wang SA. Eosinophilia with FIP1L1-PDGFRA fusion in a patient with chronic myelomonocytic leukemia. J Clin Oncol. 2008; 26:2040-1. | Article | PubMed

34. Shah S, Loghavi S, Garcia-Manero G and Khoury JD. Discovery of imatinib-responsive FIP1L1-PDGFRA mutation during refractory acute myeloid leukemia transformation of chronic myelomonocytic leukemia. J Hematol Oncol. 2014; 7:26. | Article I PubMed Abstract I PubMed FullText

35. Sorour Y, Dalley CD, Snowden JA, Cross NC and Reilly JT. Acute myeloid leukaemia with associated eosinophilia: justification for FIP1L1-PDGFRA screening in cases lacking the CBFB-MYH11 fusion gene. Br J Haematol. 2009; 146:225-7. | Article | PubMed

36. Harada $\mathrm{H}$, Harada $\mathrm{Y}$ and Eguchi $\mathrm{M}$ et al. Characterization of acute leukemia with t(4;12). Leuk Lymphoma. 1997; 25:47-53.

37. Sainty $D$, Arnoulet $C$ and Mozziconacci MJ et al. $\mathbf{t}(\mathbf{4} ; 12)(\mathbf{q 1 1} ; \mathbf{p} 13)$ in a CD7-negative acute myeloid leukemia. Br J Haematol. 1997; 96:210-212.

38. Cools J, Bilhou-Nabera C, Wlodarska I, Cabrol C, Talmant P, Bernard P, Hagemeijer A and Marynen P. Fusion of a novel gene, BTL, to ETV6 in acute myeloid leukemias with a t(4;12)(q11-q12;p13). Blood. 1999; 94:1820-4. | Article | PubMed

39. Cools J, Mentens N, Odero MD, Peeters P, Wlodarska I, Delforge M, Hagemeijer A and Marynen P. Evidence for position effects as a variant ETV6-mediated leukemogenic mechanism in myeloid leukemias with a t(4;12)(q11-q12;p13) or t(5;12)(q31;p13). Blood. 2002; 99:1776-84. | Article | PubMed

40. Yoshida M, Tamagawa N, Nakao T, Kanashima H, Ueda H, Murakami A, Yorifuji T and Yamane T. Imatinib non-responsive chronic eosinophilic leukemia with ETV6-PDGFRA fusion gene. Leuk Lymphoma. 2015; 56:768-9. | Article | PubMed

41. Hamaguchi H, Nagata K, Yamamoto K, Kobayashi M, Takashima T and Taniwaki M. A new translocation, t(2;4;12)(p21;q12;p13), in CD7positive acute myeloid leukemia: a variant form of $t(4 ; 12)$. Cancer Genet Cytogenet. 1999; 114:96-9. | Article | PubMed

42. Heaton SM, Koppitch F and Mohamed AN. A new case of $t(4 ; 12)$ (q12;p13) in a secondary acute myeloid leukemia with review of literature. Atlas Genet Cytogenet Oncol/Haematol. 2011; 15:989-991. Pdf

43. Chan PM, Ilangumaran S, La Rose J, Chakrabartty A and Rottapel R. Autoinhibition of the kit receptor tyrosine kinase by the cytosolic juxtamembrane region. Mol Cell Biol. 2003; 23:3067-78. | Article | PubMed Abstract | PubMed FullText

44. Stover EH, Chen J, Folens C, Lee BH, Mentens N, Marynen P, Williams IR, Gilliland DG and Cools J. Activation of FIP1L1-PDGFRalpha requires disruption of the juxtamembrane domain of PDGFRalpha and is FIP1L1independent. Proc Natl Acad Sci U S A. 2006; 103:8078-83. | Article | PubMed Abstract | PubMed FullText

45. Odero MD, Carlson K, Calasanz MJ, Lahortiga I, Chinwalla V and Rowley JD. Identification of new translocations involving ETV6 in hematologic malignancies by fluorescence in situ hybridization and spectral karyotyping. Genes Chromosomes Cancer. 2001; 31:134-42. | Article PubMed 
Koduru et al. Hematology and Leukemia 2016,

46. Chow YW, Pietranico R and Mukerji A. Studies of oxygen binding energy to hemoglobin molecule. Biochem Biophys Res Commun. 1975; 66:142431. | Article | PubMed

47. Harrison CJ, Moorman AV, Schwab C, Carroll AJ, Raetz EA, Devidas M, Strehl S, Nebral K, Harbott J, Teigler-Schlegel A, Zimmerman M, Dastuge N, Baruchel A, Soulier J, Auclerc MF, Attarbaschi A, Mann G, Stark B, Cazzaniga $G$ and Chilton $L$. An international study of intrachromosomal amplification of chromosome 21 (iAMP21): cytogenetic characterization and outcome. Leukemia. 2014; 28:1015-21. | Article | PubMed Abstract I PubMed FullText

48. Uckun FM, Gajl-Peczalska KJ, Provisor AJ and Heerema NA. Immunophenotype-karyotype associations in human acute lymphoblastic leukemia. Blood. 1989; 73:271-80. | Article | PubMed

49. Preiss BS, Bergmann OJ, Friis LS, Sorensen AG, Frederiksen M, Gadeberg OV, Mourits-Andersen T, Oestergaard B and Kerndrup GB. Cytogenetic findings in adult secondary acute myeloid leukemia (AML): frequency of favorable and adverse chromosomal aberrations do not differ from adult de novo AML. Cancer Genet Cytogenet. 2010; 202:108-22. | Article I PubMed

50. Whitehead VM, Vuchich MJ, Cooley L, Lauer SJ, Mahoney DH, Shuster JJ, Payment C, Bernstein ML, Akabutu JJ, Bowen T, Kamen BA, Watson MS, Look AT, Pullen DJ and Camitta B. Translocations involving chromosome 12p11-13, methotrexate metabolism, and outcome in childhood B-progenitor cell acute lymphoblastic leukemia: a Pediatric Oncology Group study. Clin Cancer Res. 1998; 4:183-8. | Article | PubMed

51. Jarosova M, Rohon P, Zivna J, Pekova S, Nedomova R, Holzerova M, Mickova P, Reptova S, Papajik T and Indrak K. Pathogenetic role of ETV6 fusion gene in leukemic transformation of myelodysplastic syndrome refractory anemia with excess blasts-1 with a new, rare translocation $\mathrm{t}(11 ; 19)(\mathrm{q} 24.3 ; \mathrm{q} 13.12)$ and insertion ins(6;12)(p22.3p13). Leuk Lymphoma. 2014; 55:950-3. | Article | PubMed

52. Sonoki T, Harder L, Horsman DE, Karran L, Taniguchi I, Willis TG, Gesk S, Steinemann D, Zucca E, Schlegelberger B, Sole F, Mungall AJ, Gascoyne $R D$, Siebert $R$ and Dyer MJ. Cyclin D3 is a target gene of $t(6 ; 14)$ (p21.1;q32.3) of mature B-cell malignancies. Blood. 2001; 98:2837-44. | Article | PubMed

53. Viguie F. t(6;14)(p21;q32). Atlas Genet Cytogenet Oncol Haematol. 2005; 2009:252-253

54. Lapunzina $P$ and Monk D. The consequences of uniparental disomy and copy number neutral loss-of-heterozygosity during human development and cancer. Biol Cell. 2011; 103:303-17. | Article | PubMed

55. Fitzgibbon J, Smith LL, Raghavan M, Smith ML, Debernardi S, Skoulakis $S$, Lillington D, Lister TA and Young BD. Association between acquired uniparental disomy and homozygous gene mutation in acute myeloid leukemias. Cancer Res. 2005; 65:9152-4. | Article | PubMed

56. Rumi E, Harutyunyan A, Elena C, Pietra D, Klampfl T, Bagienski K, Berg T, Casetti I, Pascutto C, Passamonti F, Kralovics R and Cazzola $M$. Identification of genomic aberrations associated with disease transformation by means of high-resolution SNP array analysis in patients with myeloproliferative neoplasm. Am J Hematol. 2011; 86:974-9. | Article | PubMed

57. Bullinger $L$ and Frohling $S$. Array-based cytogenetic approaches in acute myeloid leukemia: clinical impact and biological insights. Semin Oncol. 2012; 39:37-46. | Article | PubMed

58. Bullinger L, Kronke J, Schon C, Radtke I, Urlbauer K, Botzenhardt U, Gaidzik V, Cario A, Senger C, Schlenk RF, Downing JR, Holzmann K, Dohner $\mathrm{K}$ and Dohner $\mathrm{H}$. Identification of acquired copy number alterations and uniparental disomies in cytogenetically normal acute myeloid leukemia using high-resolution single-nucleotide polymorphism analysis. Leukemia. 2010; 24:438-49. | Article | PubMed

59. Costa AR, Vasudevan A, Krepischi A, Rosenberg C and Chauffaille Mde L. Single-nucleotide polymorphism-array improves detection rate of genomic alterations in core-binding factor leukemia. Med Oncol. 2013; 30:579. | Article | PubMed

60. Andreasson P, Johansson B, Billstrom R, Garwicz S, Mitelman F and Hoglund $M$. Fluorescence in situ hybridization analyses of hematologic malignancies reveal frequent cytogenetically unrecognized $12 p$ rearrangements. Leukemia. 1998; 12:390-400. | PubMed

61. Berger R, Flandrin G, Bernheim A, Le Coniat M, Vecchione D, Pacot A, Derre J, Daniel MT, Valensi F, Sigaux F and et al. Cytogenetic studies on $\mathbf{5 1 9}$ consecutive de novo acute nonlymphocytic leukemias. Cancer Genet Cytogenet. 1987; 29:9-21. | Article | PubMed

62. Chauffaille Mde L, Fermino FA, Pelloso LA, Silva MR, Bordin JO and Yamamoto M. t(4;12)(q11;p13): a rare chromosomal translocation in acute myeloid leukemia. Leuk Res. 2003; 27:363-6. | Article | PubMed

63. Chen B, Zhao WL, Jin J, Xue YQ, Cheng X, Chen XT, Cui J, Chen ZM, Cao Q, Yang G, Yao Y, Xia HL, Tong JH, Li JM, Chen J, Xiong SM, Shen ZX, Waxman $\mathrm{S}$, Chen $Z$ and Chen SJ. Clinical and cytogenetic features of 508 Chinese patients with myelodysplastic syndrome and comparison with those in Western countries. Leukemia. 2005; 19:767-75. | Article | PubMed

64. El-Rifai W, Elonen E, Larramendy M, Ruutu T and Knuutila S. Chromosomal breakpoints and changes in DNA copy number in refractory acute myeloid leukemia. Leukemia. 1997; 11:958-63. | Pdf | PubMed

65. Collaborative study of karyotypes in childhood acute lymphoblastic leukemias. Groupe Francais de Cytogenetique Hematologique. Leukemia. 1993; 7:10-9. I PubMed

66. Harada H, Asou H, Kyo T, Asaoku H, Iwato K, Dohy H, Oda K, Harada Y, Kita $\mathrm{K}$ and Kamada N. A specific chromosome abnormality of $t(4 ; 12)$ (q11-12;p13) in CD7+ acute leukaemia. Br J Haematol. 1995; 90:850-4. Article | PubMed

67. Kern W, Haferlach T, Schnittger S, Ludwig WD, Hiddemann W and Schoch C. Karyotype instability between diagnosis and relapse in $\mathbf{1 1 7}$ patients with acute myeloid leukemia: implications for resistance against therapy. Leukemia. 2002; 16:2084-91. | Article | PubMed

68. Kuchenbauer F, Schoch $\mathrm{C}$ and Holler $\mathrm{E}$ et al. A rare case of acute myeloid leukemia with a CHIC2-ETV6 fusion gene and multiple other molecular aberrations. Leukemia. 2005; 19:2366-2368. | Article

69. Ma SK, Lie AK, Au WY, Wan TS and Chan LC. CD7+ acute myeloid leukaemia with 'mature lymphoid' blast morphology, marrow basophilia and t(4;12)(q12;p13). Br J Haematol. 1997; 99:978-80. | PubMed

70. Manabe M, Nakamura K, Inaba A, Fujitani Y, Kosaka S, Yamamura R, Inoue A, Hino M, Senzaki H and Ohta K. A rare t(4;12)(q12;p13) in an adolescent patient with acute myeloid leukemia. Cancer Genet Cytogenet. 2010; 200:70-2. | Article | PubMed

71. Michaux L, Wlodarska I, Stul M, Dierlamm J, Mugneret F, Herens $C$, Beverloo B, Verhest A, Verellen-Dumoulin C, Verhoef G, Selleslag D, Madoe V, Lecomte M, Deprijck B, Ferrant A, Delannoy A, Marichal S, Duhem C, Dicato M and Hagemeijer A. MLL amplification in myeloid leukemias: A study of $\mathbf{1 4}$ cases with multiple copies of 11q23. Genes Chromosomes Cancer. 2000; 29:40-7. | Article | PubMed

72. Nathan PC, Chun K, Abdelhaleem M and Malkin D. Isochromosome (17) (q10) and translocation $(4 ; 12)(q 12 ; p 13)$ in a child with acute myeloid leukemia. Cancer Genet Cytogenet. 2001; 131:82-5. I Article | PubMed

73. den Nijs van Weert JI, Beverstock GC, Kievits T, Haak HL, Havik-Bogaard $\mathrm{FC}$ and Leeksma $\mathrm{CH}$. $\operatorname{der}(1) \mathrm{t}(1 ; 9)$ : a specific chromosome abnormality in polycythemia vera? Cytogenetic and in situ hybridization studies. Cancer Genet Cytogenet. 1989; 40:121-7. | Article | PubMed

74. Ohyashiki K. Nonrandom cytogenetic changes in human acute leukemia and their clinical implications. Cancer Genet Cytogenet. 1984; 11:453-71. I PubMed

75. Peniket A, Wainscoat J, Side L, Daly S, Kusec R, Buck G, Wheatley K, Walker H, Chatters S, Harrison C, Boultwood J, Goldstone A and Burnett A. Del (9q) AML: clinical and cytological characteristics and prognostic implications. Br J Haematol. 2005; 129:210-20. | Article | PubMed

76. van der Plas DC, Dekker I, Hagemeijer A, Hooijkaas H and Hahlen K. 12p chromosomal aberrations in precursor $B$ childhood acute lymphoblastic leukemia predict an increased risk of relapse in the central nervous system and are associated with typical blast cell morphology. Leukemia. 1994; 8:2041-6. | PubMed

77. van der Plas DC, Dekker I, Hagemeijer A, Hooijkaas H and Hahlen K. 12p chromosomal aberrations in precursor $B$ childhood acute lymphoblastic 
Koduru et al. Hematology and Leukemia 2016,

http://www.hoajonline.com/journals/pdf/2052-434X-4-1.pdf

leukemia predict an increased risk of relapse in the central nervous system and are associated with typical blast cell morphology. Leukemia. 1994; 8:2041-6. | PubMed

78. Translocations involving $12 p$ in acute myeloid leukemia: association with prior myelodysplasia and exposure to mutagenic agents. United Kingdom Cancer Cytogenetics Group (UKCCG). Genes Chromosomes Cancer. 1992; 5:252-4. | PubMed

\section{Citation:}

Koduru P, Guruju N, Patel P, Wen J, Wilson K and Monaghan S. A unique rearrangement of PDGFRa and ETV6 in a patient with acute myeloid leukemia with myelodysplasia-related changes progressed from chronic myelomonocytic leukemia. Hematol Leuk. 2016; 4:1. http://dx.doi.org/10.7243/2052-434X-4-1 